\title{
Factors influencing degree of glycosylation and phosphorylation of caseins in individual cow milk samples
}

\author{
N. A. Poulsen, ${ }^{1}$ H. B. Jensen, and L. B. Larsen \\ Department of Food Science, Aarhus University, 8830 Tjele, Denmark
}

\begin{abstract}
The aim of this study was to examine variations in posttranslational modifications (PTM) of caseins $(\mathrm{CN})$ in milk from individual cows and determine how these differ between breeds, across lactation, and between variants. Furthermore, we examined the variation of casein PTM in relation to rennet coagulation properties of milk. In total, detailed protein composition of milk from 892 Danish Holstein and Jersey cows was determined by liquid chromatography/electrospray ionization-mass spectrometry. The method measured relative contents of the main milk proteins as well as several variants and PTM. The results showed that the 2 breeds had distinct milk protein composition. Milk from Danish Holstein cows was mainly characterized by higher relative contents of $\beta$-CN, $\alpha$-lactalbumin $(\alpha-\mathrm{LA})$, and $\beta$-lactoglobulin, and a higher fraction of glycosylated $\kappa-\mathrm{CN}(\mathrm{G} \kappa-\mathrm{CN})$, whereas milk from Danish Jersey cows was characterized by higher relative contents of $\kappa-\mathrm{CN}, \alpha_{\mathrm{S}^{2}}-\mathrm{CN}$, and the less phosphorylated forms of $\alpha_{\mathrm{S}^{-}} \mathrm{CN}$ and $\alpha_{\mathrm{S}_{2}} \mathrm{CN}$. Univariate linear models including days in milk and parity as class effects showed variation in the detailed protein profile across and between lactations; in particular, changes in the degree of glycosylation of $\kappa$-CN were pronounced, but changes in $\alpha_{\mathrm{S}^{-}} \mathrm{CN} 8 \mathrm{P}$ to total $\alpha_{\mathrm{S}^{-}} \mathrm{CN}$ and $\alpha_{\mathrm{S}_{2}} \mathrm{CN}$ $11 \mathrm{P}$ to $\alpha_{\mathrm{S}_{2}} \mathrm{CN}$ were also observed over lactation for both breeds. The phosphorylated forms of $\alpha_{\mathrm{S1}^{-}} \mathrm{CN}$ and $\alpha_{S^{2}-} \mathrm{CN}$ were, to some extent, correlated. Further, the $\kappa-\mathrm{CN} B B$ genotype was associated with higher relative contents of both unglycosylated $\kappa-\mathrm{CN}(\mathrm{UG} \kappa-\mathrm{CN})$ and

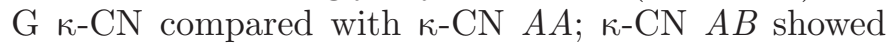
intermediate results in both breeds. The influence of protein composition on rennet coagulation properties was explored based on 4 classes for curd firming rate: noncoagulation, and poor, average, and good coagulation. The results revealed breed differences: Holstein milk, higher relative content of $\kappa-\mathrm{CN}$ to total protein, and higher content of $\mathrm{G} \kappa-\mathrm{CN}$ were associated with
\end{abstract}

Received August 7, 2015.

Accepted January 25, 2016.

${ }^{1}$ Corresponding author: Nina.Poulsen@agrsci.dk improved milk coagulation. In contrast, relative content of $\alpha$-LA was the main component associated with milk coagulation properties in Danish Jerseys and it was shown to affect milk coagulation properties negatively. In addition, variation in phosphorylation degrees of $\alpha_{\mathrm{S}^{-}}$ $\mathrm{CN}$ also played a role. This study demonstrates that although the genetic influence of glycosylation seems to be the same in both breeds, nongenetic variation differs, which is further reflected in different associations with milk coagulation properties.

Key words: posttranslational modification, glycosylation degree, mass spectrometry, milk coagulation

\section{INTRODUCTION}

A large number of genetic casein variants (Farrell et al., 2004; Caroli et al., 2009), multiple glycosylation isoforms of $\kappa-\mathrm{CN}$ (Saito and Itoh, 1992; Holland et al., 2006), and various phosphorylation sites of, particularly, $\alpha_{\mathrm{S}^{-}}$and $\alpha_{\mathrm{S} 2^{-}} \mathrm{CN}$ but also $\kappa-\mathrm{CN}$ and $\beta-\mathrm{CN}$ (Holland, 2009) result in a very heterogeneous isoform pattern of the caseins, which is still not well understood even though the sensitivity of characterization techniques has been improved. Posttranslational modifications (PTM) affect casein micelle stability, and the highly glycosylated hydrophilic part of $\kappa-\mathrm{CN}$, caseinomacropeptide (CMP), ensures electrostatic and steric repulsion between micelles in bovine milk (Dziuba and Minkiewicz, 1996). Several studies have documented that variation in $\kappa-\mathrm{CN}$ content affects casein micelle size (Frederiksen et al., 2011; Day et al., 2015), but the glycosylated part especially seems to play a major role (Bijl et al., 2014a). Thus, casein micelle size is strongly negatively correlated with the content of glycosylated of $\kappa-\mathrm{CN}(\mathbf{G} \kappa-\mathbf{C N})$ but not with the content of unglycosylated ( $\mathbf{U} \boldsymbol{\kappa}-\mathbf{C N}$ ) in milk from Montbéliarde cows (Bijl et al., 2014a). Furthermore, k-CN (CSN3) $B B$ genotypes exhibit higher relative contents of $\kappa-\mathrm{CN}$ (Heck et al., 2009; Jensen et al., 2015), which seems to be related to higher levels of both $\mathrm{U} \kappa-\mathrm{CN}$ and $\mathrm{G} \kappa-\mathrm{CN}$ relative to $A A$ genotypes (Bonfatti et al., 2014). Apart from the glycosylation of $\kappa-\mathrm{CN}$, the relative distribution of the caseins, the associated calcium phosphate 
nanocluster, and phosphorylation of phosphoserine sites of the caseins also affect the technological properties of milk. Thus, a higher fraction of the least phosphorylated forms of $\alpha_{\mathrm{S}^{-}} \mathrm{CN}$ and $\alpha_{\mathrm{S}^{2}} \mathrm{CN}$ and a higher fraction of $\mathrm{G} \kappa-\mathrm{CN}$ have been positively associated with rennet coagulation properties in milk from Danish Holstein (DH) cows (Frederiksen et al., 2011; Jensen et al., 2012), suggesting that variation in PTM plays a significant role determining the technological properties of milk.

The genetic influence on protein composition and distribution of the major milk proteins seems pronounced and thereby less affected by different feeding and management practices. The effect of the genetic amino acid polymorphisms of the caseins (or composite genotypes or haplotypes thereof) on protein composition and coagulation properties is well documented (Heck et al., 2009; Jensen et al., 2012), but other candidate genes, including genes associated with PTM, have been identified (Tyrisevä et al., 2008), suggesting that the genetic influence on coagulation properties is more complex. This is in line with the high heritabilities found for different phosphorylation forms of $\alpha_{\mathrm{S1}^{-}} \mathrm{CN}$, which suggest that variation in PTM are under strong genetic influence and that even highly similar isoforms such as $\alpha_{\mathrm{S} 1}-\mathrm{CN} 8 \mathrm{P}$ and $9 \mathrm{P}$ (where $\mathrm{P}$ indicates the number of phosphorylated groups attached) can be regulated by different genes (Bijl et al., 2014b). Changes in PTM over a lactation are less understood, however. Bonfatti et al. (2014) showed that the content of UG $\kappa-C N$ remained unchanged over lactation, whereas the relative concentration of $\mathrm{G} \kappa-\mathrm{CN}$ increased over lactation, also reflected in increasing $\mathrm{\kappa}-\mathrm{CN}$ contents and a higher degree of glycosylation. These findings suggest that the underlying mechanisms controlling regulation of PTM change over lactation.

Compared with DH cows, milk from Danish Jersey (DJ) cows has superior rennet coagulation properties, which previously have been associated with specific composite $\alpha_{\mathrm{S}^{-}}, \kappa^{-}, \beta-\mathrm{CN}$ genotypes (Poulsen et al., 2013). Thus, DJ cows have higher frequencies of genetic protein variants associated with higher protein content, higher $\kappa-\mathrm{CN}$ content, and good rennet coagulation properties (Jensen et al., 2012). The objectives of the present study were to examine variation in casein PTM and distribution in relation to breed, protein variants, and milk coagulation properties in milk from healthy mid-lactation cows from 2 major Danish dairy breeds.

\section{MATERIALS AND METHODS}

Morning milk samples were collected from 22 Danish Jersey and 20 Danish Holstein herds as described in Poulsen et al. (2013).

\section{Relative Quantification of Milk Proteins and Isoforms}

The liquid chromatography/electrospray ionizationmass spectrometry (LC/ESI-MS) procedure used in the present study was outlined in Jensen et al. (2012). This protocol was developed from previous studies (Bobe et al., 1998; Bonfatti et al., 2008; Bonizzi et al., 2009) and modified according to Frederiksen et al. (2011). Variation of the major milk proteins were determined using a reversed phase LC-based method, where protein variants and isoform PTM of selected proteins were identified with the use of ESI/MS. Proteins were separated by reversed-phase HPLC using an HPLC 1100 system (Agilent Technologies, Santa Clara, CA) with a Jupiter C4 column $(250 \mathrm{~mm} \times 2$ $\mathrm{mm}, 5$ m particle size, $300 \AA$ pores; Phenomenex, Torrance, $\mathrm{CA}$ ) operated at $40^{\circ} \mathrm{C}$ and a $\mathrm{G} 1315 \mathrm{~A}$ diode-array detector with UV detection at $214 \mathrm{~nm}$ coupled to a mass selective detector for identification and relative quantification of the milk proteins. Average molecular masses of the milk proteins were obtained using the deconvolution algorithm of the ChemStation software (rev.B.04.01 SP [650], Agilent Technologies). The procedures for sample preparation, settings for the HPLC, ESI source, and for the mass selective detector were as described by Frederiksen et al. (2011). All milk samples were analyzed in duplicate. Method reproducibility was determined by calculation of the coefficient of variation (CV) of the relative amount of individual milk proteins in a reference milk sample, run as part of each separate HPLC series. The relative protein content of the major milk proteins was calculated as the integrated peak area of a certain compound compared with total integrated peak area within each LC chromatogram.

\section{Rheological Analyses for Determination of Milk Coagulation Properties}

Rennet-induced coagulation of skim milk samples was determined by a ReoRox4 rheometer (MediRox AB, Nyköping, Sweden), as outlined in Poulsen et al. (2013). Briefly, milk samples were adjusted to $\mathrm{pH} 6.5$ with $10 \%$ (vol/vol) lactic acid and incubated for 30 min at $33^{\circ} \mathrm{C}$ before rheological analysis. Thereafter, each milk sample was set into free oscillation, and amplitude damping and frequency changes were measured continuously for $1 \mathrm{~h}$ after addition of chymosin to a final concentration of 0.04 IMCU (international milk clotting units) per mL. Each milk sample was measured as technical duplicates. Milk coagulation properties for individual samples were described as rennet coagulation time (RCT) and curd firming rate (CFR) with the ReoRox software (version 1.5.0.1055). Rennet coagulation time was defined as time from chymosin 
addition to when the phase angle reached $45^{\circ}\left(\theta=45^{\circ}\right)$, and CFR was calculated from consecutive points of the linear part of the gelation profile, defining changes in the storage modulus $\left(\mathrm{G}^{\prime}\right)$ over time $\mathrm{t},\left[\Delta \mathrm{G}^{\prime} / \Delta \mathrm{t}\right]_{\operatorname{lin}}$.

\section{Statistical Analyses}

Relative protein contents were quantified for all major casein and whey proteins, together with specific PTM forms, including $\mathrm{G} \kappa-\mathrm{CN}$ and $\mathrm{UG} \kappa-\mathrm{CN} ; \alpha_{\mathrm{S} 1}-\mathrm{CN} 8 \mathrm{P}$ and $\alpha_{S_{1}}-\mathrm{CN} 9 \mathrm{P}, \alpha_{\mathrm{S}^{2}} \mathrm{CN} 11 \mathrm{P}$ and $\alpha_{\mathrm{S}^{2}} \mathrm{CN} 12$. Furthermore, the glycosylation degree (GD) of $\kappa$-CN was defined as $\mathrm{G} \kappa-\mathrm{CN} /$ total $\kappa-\mathrm{CN}$ and the phosphorylation degrees (PD) of $\alpha_{\mathrm{S}_{1}} \mathrm{CN}$ and $\alpha_{\mathrm{S}_{2}} \mathrm{CN}$ were defined as $\alpha_{\mathrm{S}^{-}} \mathrm{CN}$ $8 \mathrm{P} /$ total $\alpha_{\mathrm{S}^{-}}-\mathrm{CN}$ and $\alpha_{\mathrm{S}_{2}}-\mathrm{CN} 11 \mathrm{P} /$ total $\alpha_{\mathrm{S} 2}-\mathrm{CN}$, respectively. Principal component analysis (PCA) of milk samples was used to explore variation between breeds in the data set using the SIMCA software (SIMCA version 14, Umetrics AB, Umeå, Sweden), where the relative protein contents, GD of $\kappa-\mathrm{CN}$, and $\mathrm{PD}$ of $\alpha_{\mathrm{S}_{1}} \mathrm{CN}$ and $\alpha_{\mathrm{S}^{2}} \mathrm{CN}$ were used as $\mathrm{X}$-variables.

One-way ANOVA was used to compare means between breeds, whereas 2-way ANOVA was used to analyze differences between average relative protein content between parities and DIM classes within breeds. Cows were in parity 1,2 , or 3 , and in 4 DIM classes: DIM1 (<158 DIM), DIM2 (159-188 DIM), DIM3 (189-218 DIM), and DIM4 (>219 DIM). Furthermore, one-way ANOVA was used to compare average relative protein composition between breeds or coagulation classes. Based on CFR, rennet coagulation properties were divided into 4 classes: noncoagulation, poor, average, and good coagulation. Noncoagulating milk samples represented noncoagulating milk in one or both duplicate measurements, a definition that is less conservative than earlier definitions (Poulsen et al., 2013). In $\mathrm{DH}$, milk samples were as follows: non $(\mathrm{CFR}=0 ; 21$ samples), poor (CFR $<6 ; 116$ samples), average (CFR $>6$ and $<12 ; 234$ samples), and good (CFR $>12 ; 81$ samples), and in DJ: non (CFR $=0 ; 2$ samples), poor (CFR $<16$; 90 samples), average (CFR $>16$ and $<27$; 251 samples), and good (CFR $>27$; 91 samples). Pairwise comparisons for all tests were done using Tukey's pairwise post hoc test. All tests were performed in $\mathrm{R}$ (version 2.15.1; http://www.r-project.org).

\section{RESULTS AND DISCUSSION}

\section{LC-MS Analysis of Protein Composition}

As outlined in Jensen et al. (2012), the method applied provided high resolution of the major milk proteins and their isoforms. The proteins eluted in the following order: $\kappa-\mathrm{CN}, \alpha_{\mathrm{S}^{2}} \mathrm{CN}, \alpha_{\mathrm{S}^{-}} \mathrm{CN}, \beta-\mathrm{CN}, \beta-\mathrm{LG}$, and $\alpha$-LA. Several protein variants had similar retention times and could therefore only be discriminated by MS analysis. $\kappa$-Casein eluted in 3 major peaks; the first peak consisted of various forms of $\mathrm{G} \kappa-\mathrm{CN}$, the second peak was $\mathrm{UG} \kappa-\mathrm{CN}$ variant $A / E-1 \mathrm{P}$ that co-eluted, and the third peak was $B-1 \mathrm{P}$. $\kappa$-Casein variant $E$ was only detected in $\mathrm{DH}$, and at a low frequency $(6.4 \%)$. For $\alpha_{S_{2}-} \mathrm{CN}$, no variant polymorphism was evident and all cows were $\alpha_{\mathrm{S}^{2}} \mathrm{CN} A A$, in accordance with Caroli et al. (2009). The 2 partially separated peaks thus represent different posttranslational phosphorylation forms, with the predominant form $\alpha_{\mathrm{S}^{2}} \mathrm{CN} A-11 \mathrm{P}$ as the first peak and $\alpha_{\mathrm{S}_{2}} \mathrm{CN} A-12 \mathrm{P}$ as the second. Likewise, $\alpha_{\mathrm{S} 1}-\mathrm{CN}$ was represented as 2 partially separated peaks, where the major peak contained $\alpha_{\mathrm{S} 1}-\mathrm{CN} B / C-8 \mathrm{P}$ and the minor $\alpha_{\mathrm{S} 1}-\mathrm{CN} B / C-9 \mathrm{P}$. Thus, separation of the variants $B$ and $C$ of $\alpha_{\mathrm{S} 1}-\mathrm{CN}$ was not possible and these were identified by MS analysis. For $\beta$-CN, the different variants of the major $5 \mathrm{P}$ phosphorylation form were well resolved. Thus, B-5P, $A^{1}-5 \mathrm{P}, A^{2} / I-5 \mathrm{P}, A^{3}-5 \mathrm{P}$, and $F-5 \mathrm{P}$ showed good separation, whereas variants $A^{2}$ and $I$ were identified by MS due to coelution. After the caseins, $\beta$-LG variants $C$ and $B$ eluted before $\alpha$-LA variant $B$ and $\beta-\mathrm{LG}$ variant $A$. The relative quantification of minor constituents, such as serum albumin and immunoglobulins, were not included, and only intact protein, not proteolytic products such as $\gamma$-CN, was included.

\section{Breed Differences in Protein and PTM Profiles}

The protein-based variant frequencies were in agreement with the DNA-based results (Poulsen et al., 2013), except for $\beta$-CN variant $F$, which was not targeted by the genotyping protocol, but could be identified by LC/ ESI-MS method applied in the current study. This variant had a very low frequency $(0.8 \%)$ in $\mathrm{DH}$ and was not found in DJ. Except for the relative content of $\mathrm{G} \kappa-\mathrm{CN}$, all other traits were significantly different between DJ and DH cows (Table 1). The PCA model confirmed the breed-specific protein composition and showed good separation of DH and DJ samples by the first component, which explained $30.8 \%$ of the total variation in the data set (Figure 1). The distinct protein profiles were reflected in significantly higher relative contents of $\beta-\mathrm{CN}, \alpha-\mathrm{LA}$, and $\beta-\mathrm{LG}$, as well as higher fractions of the most phosphorylated forms of $\alpha_{\mathrm{S}^{-}} \mathrm{CN}$ and $\alpha_{\mathrm{S2}^{2}} \mathrm{CN}$ in DH. In contrast, milk from DJ cows was characterized by significantly higher relative contents of UG $\kappa-\mathrm{CN}$, and the less-phosphorylated forms of $\alpha_{\mathrm{S1}^{-}} \mathrm{CN}$ and $\alpha_{\mathrm{S}^{2}} \mathrm{CN}$ (Table 1, Figure 1). The obtained results are in line with the results on protein profiles based on capillary zone electrophoresis (Gustavsson et al., 2014). Within breed, the relative contents of the individual proteins and their isoforms showed great variation. In 
$\mathrm{DH}, \beta-\mathrm{CN}$ had the lowest $\mathrm{CV}$ and $\mathrm{G} \kappa-\mathrm{CN}$ the highest. For DJ, total $\kappa-\mathrm{CN}$ had the lowest $\mathrm{CV}$ and $\alpha_{\mathrm{S}_{2}} \mathrm{CN}$ $12 \mathrm{P}$ the highest. The PD of $\alpha_{\mathrm{S}_{1}} \mathrm{CN}$ and $\alpha_{\mathrm{S}^{2}} \mathrm{CN}$ had very low $\mathrm{CV}$, whereas the GD of $\kappa-\mathrm{CN}$ varied more. The observed low $\mathrm{CV}$ for $\beta-\mathrm{CN}$ and total $\alpha_{\mathrm{S} 1}-\mathrm{CN}$ is in line with the capillary zone electrophoresis-based result in Dutch Holsteins (Heck et al., 2008). Generally, the major proteins were not strongly correlated (data not shown), except the relative concentrations of $\alpha$-LA and $\beta$-LG, which were highly positively correlated in $\mathrm{DH}$ $(\mathrm{r}=0.60, \mathrm{DJ} ; \mathrm{r}=0.38)$. Correlations between PTM isoforms of $\mathrm{CN}$ can be seen in Table 2. The correlations between $\alpha_{S_{1}-} \mathrm{CN} 8 \mathrm{P}$ and $9 \mathrm{P}$ were relatively low in both breeds, and were in line with other studies (Heck et al., 2008; Bijl et al., 2014b). Bijl et al. (2014b) showed that $\alpha_{\mathrm{S1}^{-}} \mathrm{CN} 8 \mathrm{P}$ and $9 \mathrm{P}$ are most likely regulated by different genes, which might also explain the low phenotypic correlation observed here. In contrast, $\alpha_{S_{2}-} \mathrm{CN} 11 \mathrm{P}$ and $12 \mathrm{P}$ were relatively highly positively correlated in both breeds, which might suggest a common genetic influence. Heck et al. (2008) found a very strong negative correlation between $\alpha_{\mathrm{S}_{2}} \mathrm{CN} 11 \mathrm{P}$ and $\alpha_{\mathrm{S} 1}-\mathrm{CN} 9 \mathrm{P}$ $(-0.74)$. This was only partly confirmed here (DJ: $\mathrm{r}=$ $-0.43, \mathrm{DH}: \mathrm{r}=-0.38)$. Further, the PD of $\alpha_{\mathrm{S} 1}-\mathrm{CN}$ and $\alpha_{\mathrm{S} 2}$-CN were positively correlated in both breeds, which might suggest some common relationship between the phosphorylation forms of different $\mathrm{CN}$.

\section{Effect of DIM and Parity on PTM Isoforms}

Especially in DJ, DIM and parity significantly affected protein composition (Table 3). This could, to
A

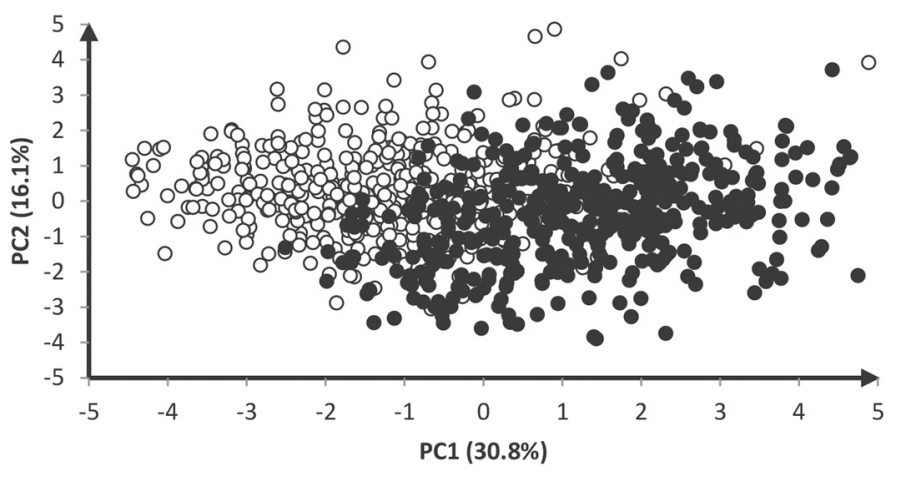

B

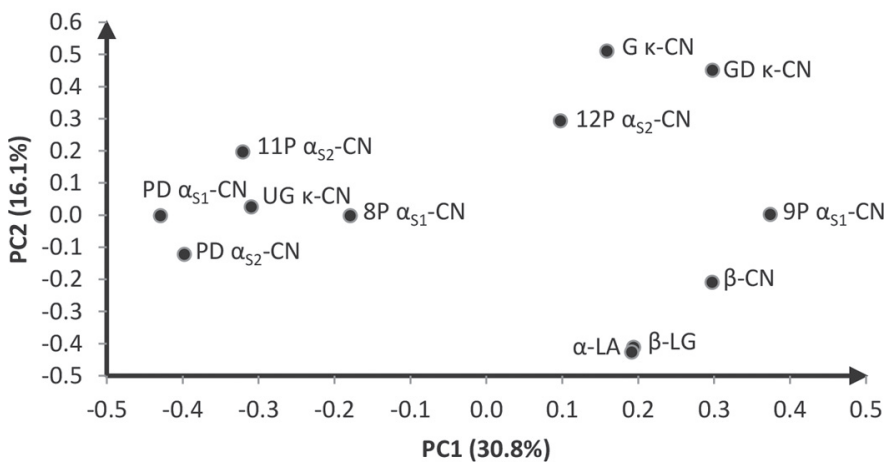

Figure 1. Principal component (PC) analysis of milk samples from Danish Holstein $(\bullet, D H)$ and Danish Jersey $(\mathrm{O}, \mathrm{DJ})$ cows, where the relative protein concentrations as a fraction of total protein, phosphorylation, and glycosylation degree were used as X-variables: (A) plot of scores; (B) plot of loadings. $\mathrm{P}=$ the number of phosphorylated groups attached; $\mathrm{G}=$ glycosylated; $\mathrm{UG}=$ unglycosylated; $\mathrm{GD}=$ glycosylation degree; $\mathrm{PD}=$ phosphorylation degree.

Table 1. Descriptive relative protein composition $^{1}$ and protein content in Danish Holstein and Jersey cows

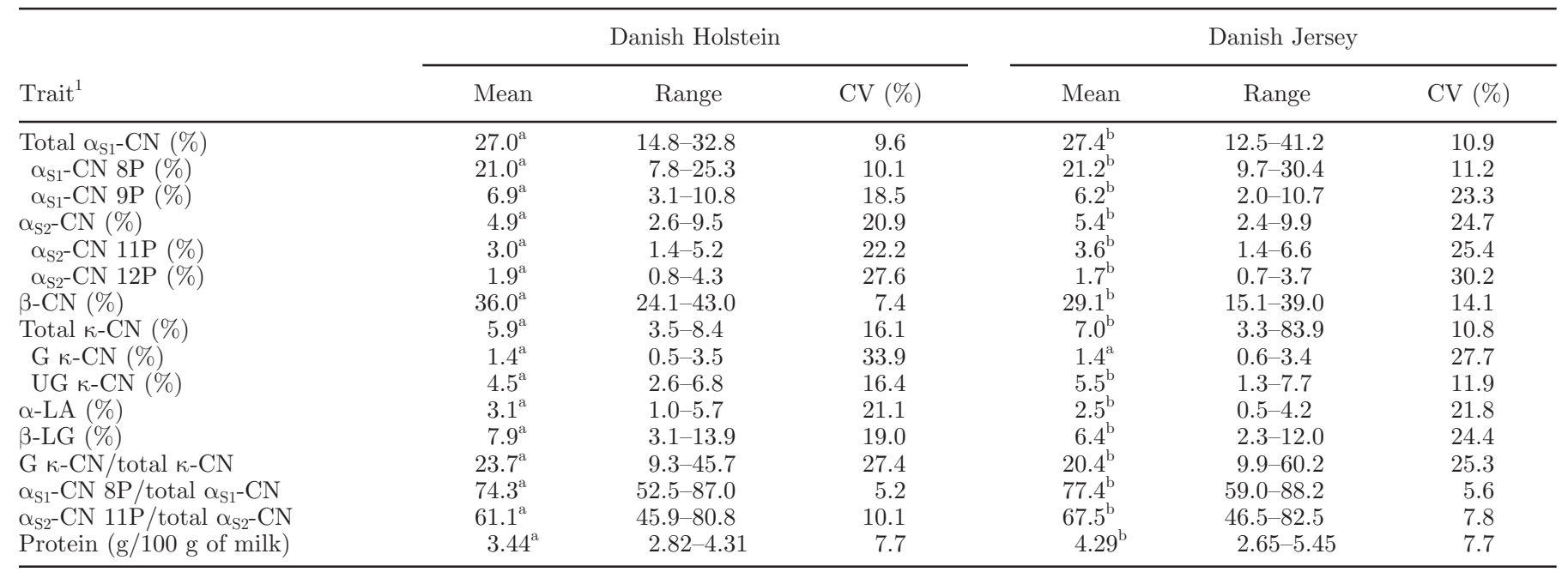

$\overline{\mathrm{a}, \mathrm{b}}$ Values with different superscripts within a row indicate significant trait variation $(P<0.05)$ between Danish Holstein and Danish Jersey cows. ${ }^{1} \mathrm{G}=$ glycosylated; $\mathrm{UG}=$ unglycosylated; $\mathrm{P}=$ the number of phosphorylated groups attached. The individual proteins comprise only the peaks identified as intact protein and isoforms marked in Jensen et al. (2012); that is, $\alpha_{\mathrm{S1}}-\mathrm{CN}\left(\alpha_{\mathrm{S1}_{1}} \mathrm{CN} 8 \mathrm{P}+9 \mathrm{P}\right), \alpha_{\mathrm{S2}}-\mathrm{CN}\left(\alpha_{\mathrm{S2}-} \mathrm{CN} 11 \mathrm{P}+12 \mathrm{P}\right), \beta-\mathrm{CN}$ $(\beta-\mathrm{CN} 5 \mathrm{P}), \kappa-\mathrm{CN}(\kappa-\mathrm{CN} \mathrm{G}+1 \mathrm{P})$. 
Table 2. Pearson correlation coefficients (r) between glycosylation and phosphorylation forms of $\kappa-\mathrm{CN}, \alpha_{\mathrm{S1} 1} \mathrm{CN}$, and $\alpha_{\mathrm{S2} 2} \mathrm{CN}$ in Danish Holstein (above diagonal) and Danish Jersey (below diagonal)

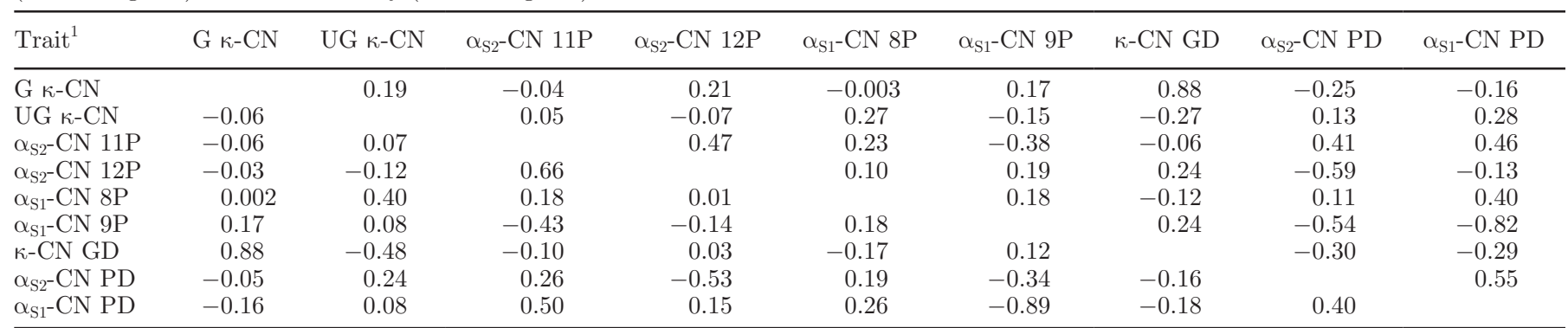

${ }^{1} \mathrm{G}=$ glycosylated; UG = unglycosylated; $\mathrm{P}=$ the number of phosphorylated groups attached; $\mathrm{GD}=$ glycosylation degree; PD = phosphorylation degree.

some extent, be a result of the different distribution of cows between DIM groups in the 2 breeds, as DH had only 10 cows in the $>219$ DIM category. In DH, total $\kappa-\mathrm{CN}$ content in particular varied across DIM classes compared with the contents of other proteins and it increased over lactation, which was related to increasing contents of $\mathrm{G} \kappa$-CN across DIM classes rather than changes in UG $\kappa-\mathrm{CN}$ content (Table 3). These results are in line with the findings of others (Robitaille et al., 1991; Bonfatti et al., 2014) and suggest that regulatory changes in relation to PTM of $\kappa-\mathrm{CN}$ occur over lactation. Days in milk also affected both $\mathrm{G} \kappa-\mathrm{CN}$ and $\mathrm{UG} \kappa-\mathrm{CN}$ in DJ, but in contrast to $\mathrm{DH}$, the contents of $\mathrm{G} \kappa-\mathrm{CN}$ and $\mathrm{UG} \kappa-\mathrm{CN}$ decreased over lactation, also resulting in lower GD in later lactation (Table 3). Changes in PD of $\alpha_{\mathrm{S}_{1}}-\mathrm{CN}$ and $\alpha_{\mathrm{S}_{2}} \mathrm{CN}$ were more consistent across breeds (Table 3); lower PD were documented in DIM3 compared with DIM1 and DIM2, but a tendency toward higher PD in DIM4 compared with DIM3 was noted. Posttranslational modification of casein occurs in the Golgi apparatus, after formation of the polypeptide chain, and determines protein function. Therefore, the alteration of PTM over lactation could indicate changes in protein function, which might be related to the lactation cycle of the cow or could play an evolutionary role for the neonatal calf. Such changes over lactation can affect the nutritional and technological quality of the milk delivered to dairies. However, in Denmark, where calving is distributed over the whole year, such effects will be mixed in bulk milk tanks and therefore not lead to seasonal variation at the dairy.

Table 3. Relative protein composition and protein content (mean) in different DIM classes ${ }^{1}$ and effect of DIM and parity (PAR) on relative protein composition and protein content in Danish Holstein and Danish Jersey cows

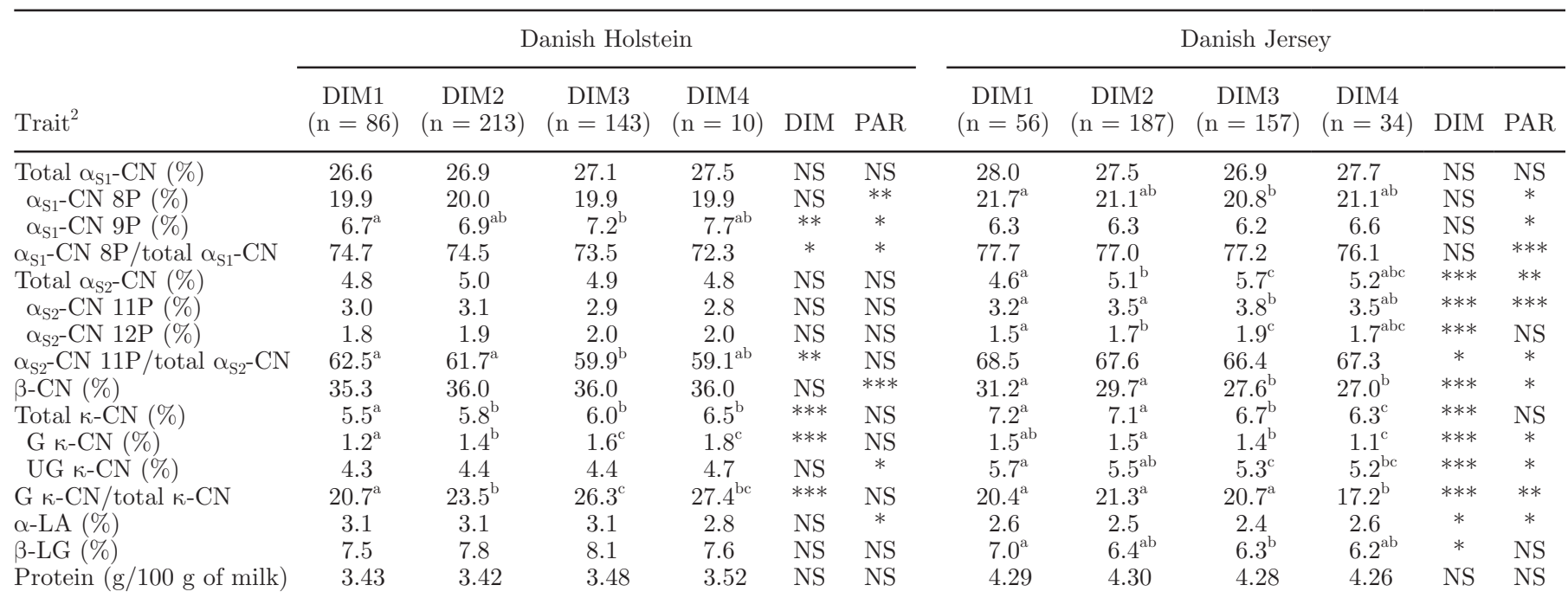

${ }^{a-c}$ Means with different superscripts indicate that DIM groups differ within breed $(P<0.05)$.

${ }^{1}$ DIM1 $=<158$ DIM, DIM2 = 159-188 DIM, DIM3 = 189-218 DIM, and DIM4 = >219 DIM.

${ }^{2} \mathrm{P}=$ the number of phosphorylated groups attached; $\mathrm{G}=$ glycosylated; $\mathrm{UG}=$ unglycosylated.

${ }^{*} P<0.05,{ }^{* *} P<0.01,{ }^{* * *} P<0.001$ (significance of the 2 -way ANOVA). 


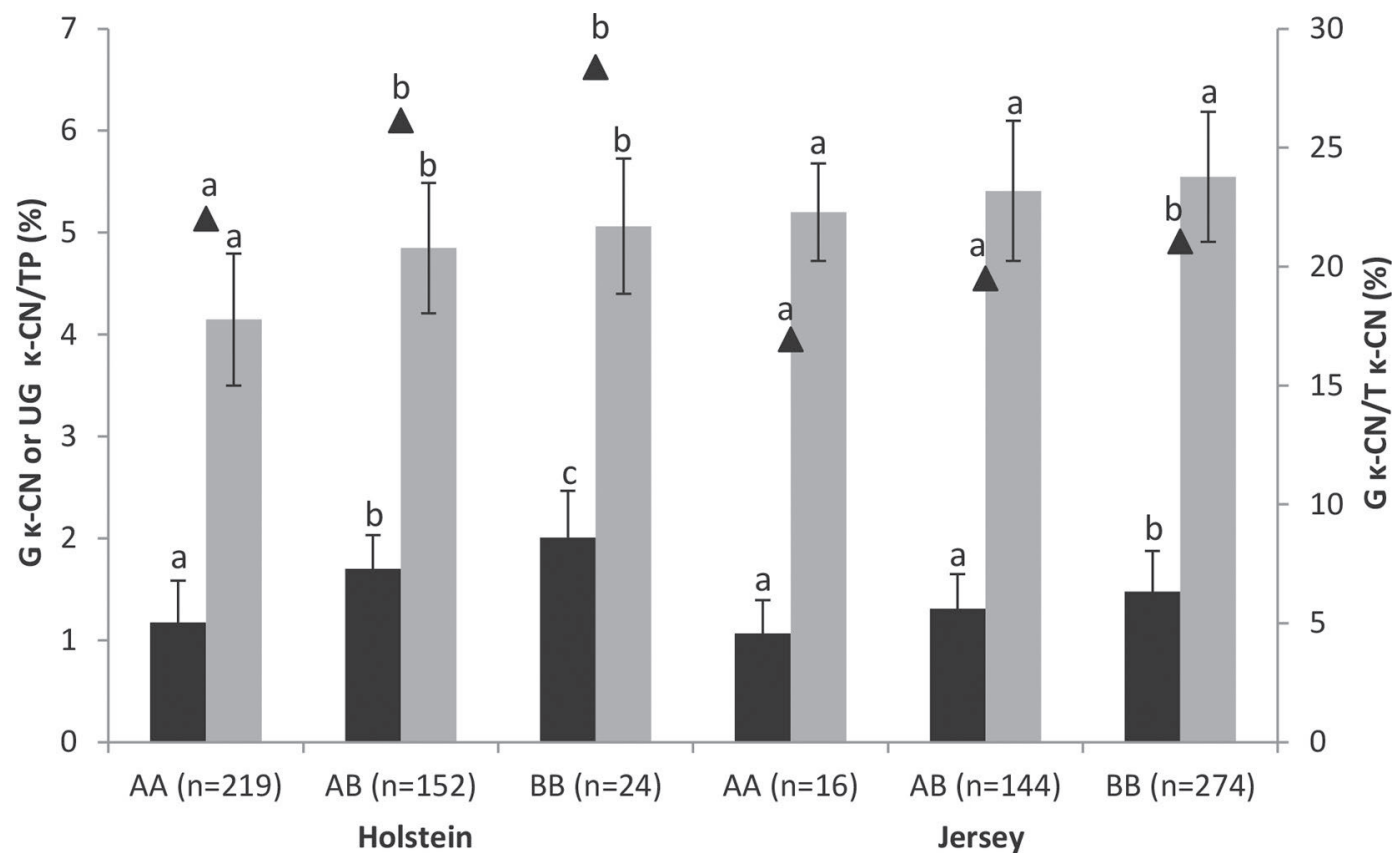

Figure 2. Content $(\%)$ of glycosylated $\kappa$-CN relative to total protein $(\mathrm{G} \kappa-\mathrm{CN} / \mathrm{TP}$; mean $\pm \mathrm{SD}$, black), unglycosylated $\kappa$-CN relative to total protein ( $\mathrm{UG} \kappa-\mathrm{CN} / \mathrm{TP}$; mean $\pm \mathrm{SD}$, gray), and glycosylation degree $(\mathrm{G} \kappa-\mathrm{CN} / \kappa-\mathrm{CN}$, mean, $\boldsymbol{\Delta})$ in milk from Danish Holstein and Jersey cows having $\mathrm{k}-\mathrm{CN} A A, A B$, and $B B$ phenotypes. Letters $(\mathrm{a}-\mathrm{c})$ denote when contents differ within breeds $(P<0.05)$.

\section{Effect of $\mathrm{K}$-CN Variants on Glycosylation}

The $\kappa$-CN variants showed strong effects on $\mathrm{G} \kappa-\mathrm{CN}$ and UG $\kappa$-CN in both DJ and DH. $\kappa$-Casein $B B$ milk had significantly higher content of $\mathrm{G} \kappa-\mathrm{CN}$ and $\mathrm{UG}$ к-CN compared with $\kappa-\mathrm{CN} A A$ in $\mathrm{DH}$ and significantly higher levels of $\mathrm{G} \kappa-\mathrm{CN}$ in $\mathrm{DJ}$; $\kappa-\mathrm{CN} A B$ showed intermediate levels (Figure 2). In $\mathrm{DH}$, the frequency of $\kappa-\mathrm{CN} B$ is low compared with DJ (Poulsen et al., 2013), which probably explains the lack of difference in mean levels of $\mathrm{G} \kappa-\mathrm{CN}$ between breeds, whereas the lower content of $\mathrm{UG} \kappa-\mathrm{CN}$ and total $\kappa-\mathrm{CN}$ in $\mathrm{DH}$ is also observed at the breed level. Others have found $\kappa-\mathrm{CN} B$ to be more glycosylated than $\kappa$-CN $A$ (Robitaille et al., 1991; Coolbear et al., 1996), and our findings confirm that ${ }-\mathrm{CN} B B$ is associated with higher contents of $\mathrm{G}$ $\kappa-\mathrm{CN}$ and $\mathrm{UG} \kappa-\mathrm{CN}$ and a higher GD, in an additive genetic manner, as observed by Bonfatti et al. (2014). Bijl et al. (2014a) documented that milk with CSN3 $A B$ and $A A$ genotypes had larger casein micelles than $B B$ genotypes. However, the association between GD of $\kappa-\mathrm{CN}$ and micelle size is not clear. Recently, Day et al. (2015) found that an increased proportion of $\mathrm{G} \kappa-\mathrm{CN}$ was associated with smaller micelles, which supports the findings of Bijl et al. (2014a). Interestingly, DH had higher GD for all genotypes compared with DJ. This might be related to the lower total content of $\kappa$-CN, which is most likely associated with larger micelles for all DH milk samples compared with DJ milk. However, as micelle size was not determined here, we can only speculate about such relationships. $\kappa$-Casein $B B$ milk had higher protein content compared with $\kappa-\mathrm{CN} A B$ and $\kappa-\mathrm{CN} A A$ milks (results not shown), and the superior coagulation properties observed in $B B$ genotypes (Poulsen et al., 2013) are therefore a combined result of higher protein content, higher content of $\mathrm{G} \kappa-\mathrm{CN}$, and thus probably smaller micelles. A high frequency of $\kappa-\mathrm{CN} B$ in DJ is thus beneficial for milk coagulation properties.

\section{Effect of Protein Composition on Rennet Coagulation Properties}

The effect of protein composition traits on rennet coagulation properties varied across breeds. In $\mathrm{DH}$, a higher relative content of total $\kappa-\mathrm{CN}$ to total protein and higher GD of $\kappa-\mathrm{CN}$ were strongly associated with improved milk coagulation (Figure 3A and 3B). Danish Jerseys showed the same tendencies but this was not significant. Jensen et al. (2015) found that G $\mathrm{k}$-CN isoforms showed a lower reaction rate of CMP release compared with UG $\kappa-\mathrm{CN}$, suggesting that glycan modifications affect the cleavage of $\kappa-\mathrm{CN}$ negatively, which has been shown by others (van Hooydonk et al., 1984; Ferron-Baumy et al., 1992). However, Bonfatti 
et al. (2014) found that higher contents of $\mathrm{G} \kappa-\mathrm{CN}$ were associated with shorter RCT, whereas higher concentrations of $\mathrm{U} \kappa-\mathrm{CN}$ and $\mathrm{G} \kappa-\mathrm{CN}$ were related to increased gel firmness, suggesting a positive effect during aggregation, which was also observed by others
(Robitaille et al., 1993). Smaller casein micelles are associated with improved milk coagulation (Glantz et al., 2010), and the observed negative correlation between the content of $\mathrm{G} \kappa-\mathrm{CN}$ and casein micelle size (Bijl et al., 2014a; Day et al., 2015) might therefore explain the
A

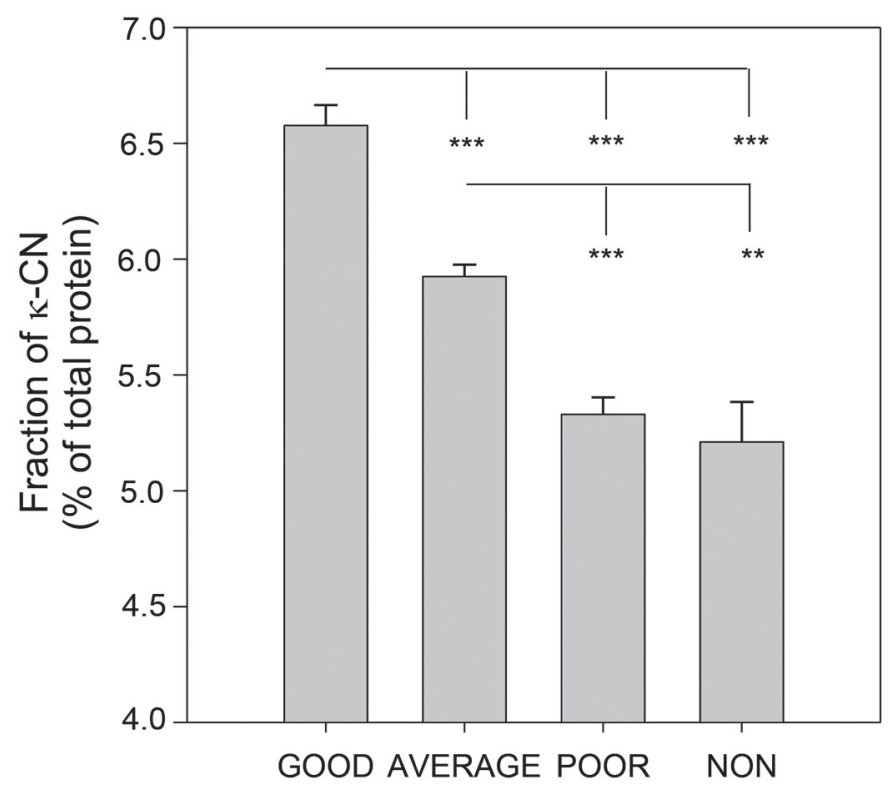

C

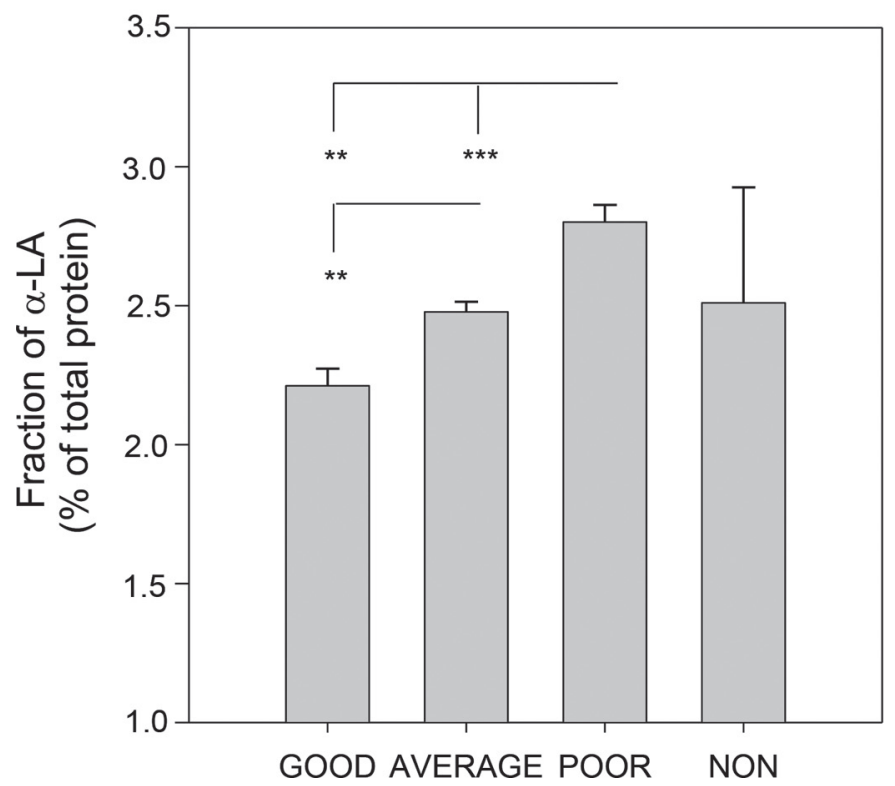

B

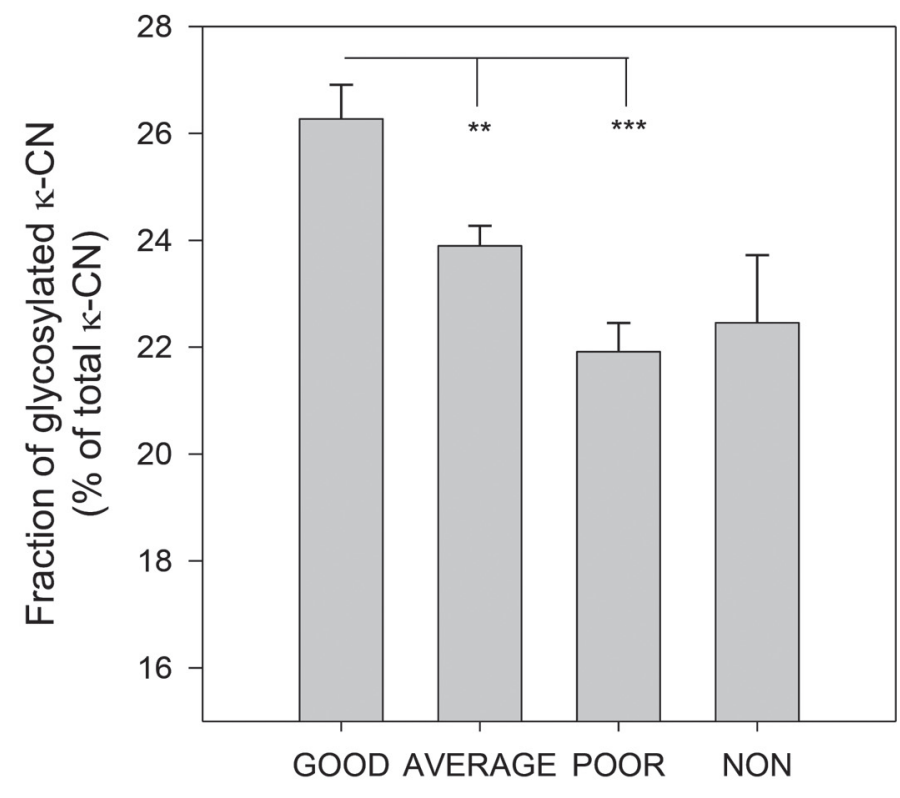

D

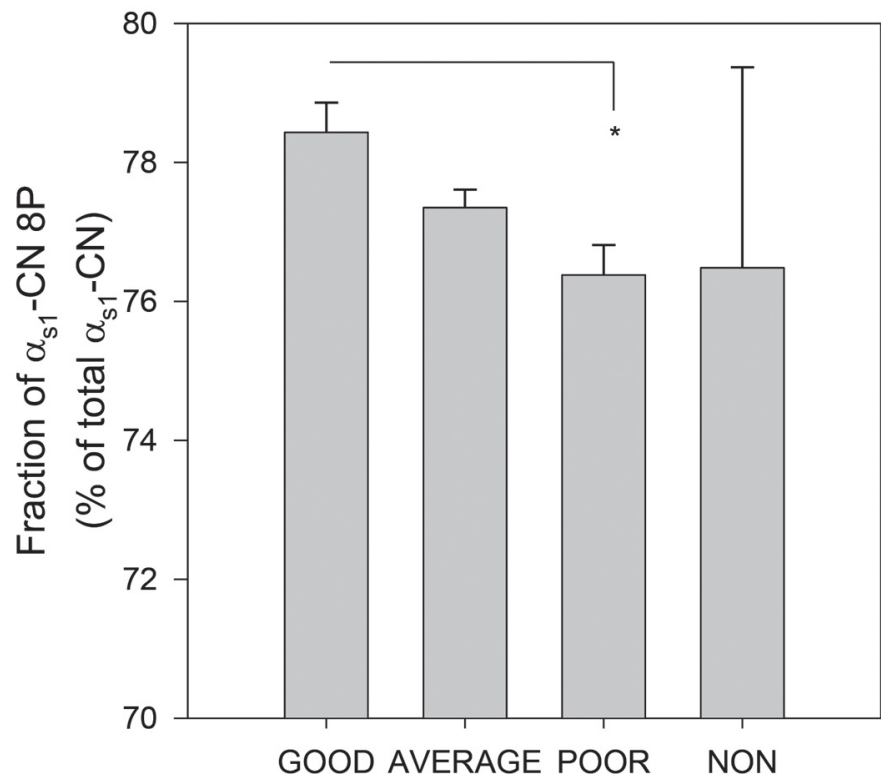

Figure 3. Difference among coagulation groups (good, average, poor, or no coagulation) in relative protein contents (\%; mean \pm SE). (A) Fraction of $\kappa$-CN relative to total protein in milk from Danish Holstein samples; (B) fraction of glycosylated $\kappa$-CN relative to total $\kappa$-CN in milk from Danish Holstein; (C) fraction of $\alpha$-LA relative to total protein in milk from Danish Jersey; (D) fraction of phosphorylated $\alpha_{\mathrm{S} 1}-\mathrm{CN} 8 \mathrm{P}$

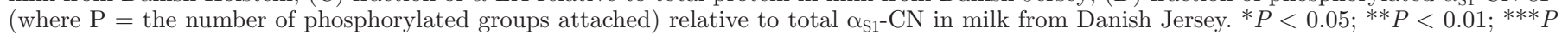
$<0.001$. 
positive association between the GD of $\kappa-\mathrm{CN}$ and milk coagulation properties, with smaller micelle size being related to higher proportions of $\mathrm{G} \kappa-\mathrm{CN}$.

In DJ, the relative content of $\alpha$-LA was shown to affect milk coagulation negatively (Figure 3C). The association between $\alpha$-LA and rennet coagulation properties might be related to effects on the caseinto-whey ratio, as the relative concentrations of $\alpha$-LA and $\beta$-LG are positively correlated and thus increasing relative contents of the whey proteins would lower the casein-to-whey ratio. In addition, the role of $\alpha$-LA in lactose synthesis, and thus milk volume, might partly explain the negative association. An increased amount of $\alpha$-LA has been documented in milk from cows in mid lactation (Zhang et al., 2015), which is probably related to higher milk volume and thus more diluted milk, which could negatively affect milk coagulation. In DJ (and with the same tendency in DH), improved milk coagulation was also associated with a higher fraction of the least phosphorylated form of $\alpha_{\mathrm{S}_{1}} \mathrm{CN}$. The same tendency was observed for $\alpha_{S_{2}} \mathrm{CN}$ in both breeds, which confirms earlier findings (Frederiksen et al., 2011; Jensen et al., 2012). The relationship between the lower proportion of $\alpha_{\mathrm{S}_{1}} \mathrm{CN} 9 \mathrm{P}$ to $\alpha_{\mathrm{S}_{1}} \mathrm{CN} 8 \mathrm{P}$ and $\alpha_{\mathrm{S}_{2}} \mathrm{CN}$ $12 \mathrm{P}$ to $\alpha_{S_{2}}-\mathrm{CN} 11 \mathrm{P}$ and improved curd firmness is not clear. Interestingly, Bijl et al. (2014c) found increased hydrolysis by chymosin of $\alpha_{\mathrm{S}_{1}} \mathrm{CN} 8 \mathrm{P}$ compared with $\alpha_{\mathrm{S}_{1}} \mathrm{CN}$ 9P in milk gels, which could indicate a different arrangement of these isoforms in the casein micelle. We found no difference between the poor-coagulating and noncoagulating groups in any of the traits examined, and the results of the current study therefore do not contribute to our understanding of noncoagulation as a trait different from poor coagulation. Overall, the results suggest that in milk from $\mathrm{DH}$ cows, where the total protein content is lower, the relative content of $\kappa-\mathrm{CN}$ to total protein is more important for renneting properties. We can speculate, therefore, that the variation in coagulation properties in DJ is, to a large extent, explained by the protein content, whereas in DH milk (represented by a lower protein content that varies less, as well as higher fractions of $\beta-\mathrm{CN}$ and whey proteins), the relative concentration of $\kappa$-CN becomes more important. Overall, the results show that the association between rennet coagulation properties and protein composition is not straightforward and that different factors and underlying genetic influence might be at play.

\section{CONCLUSIONS}

Milk protein composition and distribution were measured in a large number of individual milk samples from the 2 major Danish dairy breeds, and breed- specific protein profiles were documented. The protein profile was shown to change over and across lactations. $\kappa$-Casein variants had a strong effect on relative contents of glycosylated and unglycosylated $\kappa-\mathrm{CN}$, which was consistent across breeds. Furthermore, we examined the association between rennet coagulation properties and protein composition and documented that variation in glycosylated and unglycosylated $\kappa-\mathrm{CN}$ was more important for renneting properties in $\mathrm{DH}$, whereas $\alpha$-LA content was more related to variation in milk coagulation properties in DJ.

\section{ACKNOWLEDGMENTS}

The authors thank Arla Foods Amba (Viby J, Denmark), The Danish Cattle Federation (Aarhus, Denmark), the Danish Strategic Research Council (Copenhagen K, Denmark), and Aarhus University (Aarhus, Denmark) for financial support through the project "Milk Genomics - impact of genes for variation in milk composition and quality," which is part of the Danish-Swedish Milk Genomic Initiative. The authors also thank Hanne Søndergaard Møller and Gitte Hald Kristiansen (Department of Food Science, Aarhus University, Denmark) for excellent technical assistance.

\section{REFERENCES}

Bijl, E., R. de Vries, H. van Valenberg, T. Huppertz, and T. van Hooijdonk. 2014a. Factors influencing casein micelle size in milk of individual cows: Genetic variants and glycosylation of $\kappa$-casein. Int. Dairy J. 34:135-141.

Bijl, E., H. van Valenberg, S. Sikkes, S. Jumelet, G. Sala, K. Olieman, T. van Hooijdonk, and T. Huppertz. 2014c. Chymosin-induced hydrolysis of caseins: Influence of degree of phosphorylation of alpha-s1-casein and genetic variants of beta-casein. Int. Dairy J. $39: 215-221$.

Bijl, E., H. J. F. van Valenberg, T. Huppertz, A. C. M. van Hooijdonk, and H. Bovenhuis. 2014b. Phosphorylation of $\alpha_{\mathrm{SI}_{1}}$-casein is regulated by different genes. J. Dairy Sci. 97:7240-7246.

Bobe, G., D. C. Beitz, A. E. Freeman, and G. L. Lindberg. 1998. Separation and quantification of bovine milk proteins by reversed-phase high-performance liquid chromatography. J. Agric. Food Chem. 46:458-463.

Bonfatti, V., G. Chiarot, and P. Carnier. 2014. Glycosylation of $\kappa$-casein: Genetic and nongenetic variation and effects on rennet coagulation properties of milk. J. Dairy Sci. 97:1961-1969.

Bonfatti, V., L. Grigoletto, A. Cecchinato, L. Gallo, and P. Carnier. 2008. Validation of a new reversed-phase high-performance liquid chromatography method for separation and quantification of bovine milk protein genetic variants. J. Chromatogr. A 1195:101-106.

Bonizzi, I., J. N. Buffoni, and M. Feligini. 2009. Quantification of bovine casein fractions by direct chromatographic analysis of milk: Approaching the application to a real production context. J. Chromatogr. A 1216:165-168.

Caroli, A. M., S. Cheesa, and G. J. Erhardt. 2009. Invited review: Milk protein polymorphisms in cattle: Effect on animal breeding and human nutrition. J. Dairy Sci. 92:5335-5352.

Coolbear, K. P., D. F. Elgar, and J. S. Ayers. 1996. Profiling of genetic variants of bovine $\kappa$-casein macropeptide by electrophoretic and chromatographic techniques. Int. Dairy J. 6:1055-1068. 
Day, L., R. P. W. Williams, D. Otter, and M. A. Augustin. 2015. Casein polymorphism heterogeneity influences casein micelle size in milk of individual cows. J. Dairy Sci. 98:3633-3644.

Dziuba, J., and P. Minkiewicz. 1996. Influence of glycosylation on micelle-stabilizing ability and biological properties of C-terminal fragments of cow's א-casein. Int. Dairy J. 6:1017-1044.

Farrell, H. M., Jr., R. Jimenez-Flores, G. T. Bleck, E. M. Brown, J. E. Butler, L. K. Creamer, C. L. Hicks, C. M. Hollar, K. F. Ng-KwaiHang, and H. E. Swaisgood. 2004. Nomenclature of the proteins of cows' milk - Sixth revision. J. Dairy Sci. 87:1641-1674.

Ferron-Baumy, C., D. Molle, G. Garric, and J. Maubois. 1992. Characterization of caseinomacropeptides released from renneted raw and UHT treated milks. Lait 72:165-173.

Frederiksen, P. D., K. K. Andersen, M. Hammersh øj, H. D. Poulsen, J. Sørensen, M. Bakman, K. B. Qvist, and L. B. Larsen. 2011. Composition and effect of blending of noncoagulating, poorly coagulating, and well-coagulating bovine milk from individual Danish Holstein cows. J. Dairy Sci. 94:4787-4799.

Glantz, M., T. G. Devold, G. E. Vegarud, H. L. Månnson, H. Stålhammer, and M. Paulsson. 2010. Importance of casein micelle size and milk composition for milk gelation. J. Dairy Sci. 93:1444-1451.

Gustavsson, F., A. J. Buitenhuis, M. Johansson, H. P. Bertelsen, M. Glantz, N. A. Poulsen, H. L. Månsson, H. Stålhammar, L. B. Larsen, C. Bendixen, M. Paulsson, and A. Andrén. 2014. Effects of breed and casein genetic variants on protein profile in milk from Swedish Red, Danish Holstein and Danish Jersey cow. J. Dairy Sci. 97:3866-3877.

Heck, J. M. L., C. Olieman, A. Schennink, H. J. F. van Valenberg, M. H. P. W. Visker, R. C. R. Meuldijk, and A. C. M. van Hooijdonk. 2008. Estimation of variation in concentration, phosphorylation and genetic polymorphism of milk proteins using capillary zone electrophoresis. Int. Dairy J. 18:548-555.

Heck, J. M. L., A. Schennink, H. J. F. van Valenberg, H. Bovenhuis, M. H. P. W. Visker, J. A. M. van Arendonk, and A. C. M. van Hooijdonk. 2009. Effects of milk protein variants on the protein composition of bovine milk. J. Dairy Sci. 92:1192-1202.

Holland, J. W. 2009. Post-translational modifications of casein. Pages 107-132 in Milk Proteins: From Expression to Food. A. Thompson, M. Boland, and H. Singh, ed. Academic Press, Elsevier, San Diego, CA.
Holland, J. W., H. C. Deeth, and P. F. Alewood. 2006. Resolution and characterisation of multiple isoforms of bovine $\kappa$-casein by 2-DE following a reversible cysteine-tagging enrichment strategy. Proteomics 6:3087-3095.

Jensen, H. B., K. S. Pedersen, L. B. Johansen, N. A. Poulsen, M. Bakman, D. E. W. Chatterton, and L. B. Larsen. 2015. Genetic variation and posttranslational modification of bovine $\kappa$-casein: Effects of caseino-macropeptide release during renneting. J. Dairy Sci. 98:747-758.

Jensen, H. B., N. A. Poulsen, K. K. Andersen, M. Hammershøj, H. D. Poulsen, and L. B. Larsen. 2012. Distinct composition of bovine milk from Jersey and Holstein-Friesian cows with good, poor, or noncoagulation properties as reflected in protein genetic variants and isoforms. J. Dairy Sci. 95:6905-6917.

Poulsen, N. A., H. P. Bertelsen, H. B. Jensen, F. Gustavsson, M. Glantz, H. L. Månsson, A. Andrén, M. Paulsson, C. Bendixen, A. J. Buitenhuis, and L. B. Larsen. 2013. The occurrence of noncoagulating milk and the association of bovine milk coagulation properties with genetic variants of the caseins in 3 Scandinavian dairy breeds. J. Dairy Sci. 96:4830-4842.

Robitaille, G., K.-F. Ng-Kwai-Hang, and H. G. Monardes. 1991. Variation in the $\mathrm{N}$-acetyl neuraminic acid content of bovine $\kappa$-casein. J. Dairy Res. 58:107-114.

Robitaille, G., K. F. Ng-Kwai-Hang, and H. G. Monardes. 1993. Effect of kappa-casein glycosylation on cheese yielding capacity and coagulating properties of milk. Food Res. Int. 26:365-369.

Saito, T., and T. Itoh. 1992. Variations and distribution of O-glycosidically linked sugar chains in bovine $\kappa$-casein. J. Dairy Sci $75: 1768-1774$.

Tyrisevä, A. M., K. Elo, A. Kuusipuro, V. Vilva, I. Jänönen, H. Karjalainen, T. Ikonen, and M. Ojala. 2008. Chromosomal regions underlying noncoagulation of milk in Finnish Ayrshire cows. Genetics 180:1211-1220.

van Hooydonk, A. C. M., C. Olieman, and H. G. Hagedoorn. 1984. Kinetics of the chymosin-catalyzed proteolysis of $\kappa$-casein in milk. Neth. Milk Dairy J. 38:207-222.

Zhang, L., S. Boeren, J. A. Hageman, T. van Hooijdonk, J. Vervoort, and K. Hettinga. 2015. Perspective on calf and mammary gland development through changes in the bovine milk proteome over a complete lactation. J. Dairy Sci. 98:5362-5373. 